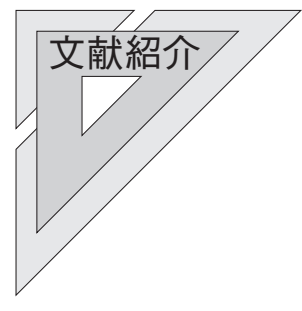

Lo-Johanson, Ivar, Ålderdoms-Sverige (1952) + Ålderdom (1949)

イーヴァル・ロー＝ヨハンソン（著）西下彰俊・兼松麻紀子・渡辺博明（編訳）

\title{
スウェーデン：高齢者福祉改革の原点 一ルポルタージュからの問題提起-
}

2013 年, 新評論, ISBN 978-4-7948-0923-0, 定価（2,800 円十税）

金賁 任

1970 年代末からイギリスをはじめ「小さな政 府」を標榜する「新保守主義」の政権が登場した が，スウェーデンは「高福祉・高負担」を目指す 「社会民主主義レジーム」である。その背景には， 地方分権の考え方があり,「平等」と「連帯」の 原理のもとですべての国民が必要なサービスを享 受できるようにし, 納税者にとって税金の使い道 が見えやすく, 当事者参加の論理, 人間性重視と いう点で学ぶべきものが多い。しかし, 近年で は, 第 1 次 F. レインフェルト保守中道連立政権 による介護サービスの民間化と市場化の加速によ り，介護市場における民間部門の寡占状態など否 定的な側面が報告されている.

このようなスウェーデンであるが，本書の目的 は, その前史として 1950 年前後の入所施設の強 制収容など，高齢者に対する「非人道的」行為が あったことを明らかにすることであった，以下で は，各章を概観していこう。

1 章では, 1930 年代半ばから出生率が減少し, 入所施設の創設が始まったことが記述されてい る. 2 章では, 高齢者問題を解決するために, 高 齢者をエッテステューパという崖から突き落とす という儀礼的行為があったことが示された. 3 章 では, 老人ホームで強制収容が自由に行われてお り, 介護訓練を受けていない職員もいるので, 介 護の質が低いことが説明されている４4章では, 個々人の高齢者の尊厳が無視され, 高齢者の統一 性と同質性が重視されていることが示された。

5 章では, 老人ホームでの恋愛は禁止されてい るが, 性愛は人生が機能している証であると論じ ている. 6 章では, 社会は高齢者の施設入所を望 むが，高齢者は入所を拒否していることが言及さ

きむじょんにむ：東京福祉大学
れている、7章では，年金受給者組合が結成さ れ，活動が次第に活発になり，人間としての権利 が保障されることを要求したことが提示されてい る. 8 章では，入所定員が多いので，入所者が逃 げないように，強制的な措置をしていることが指 摘されている.9章では, 高齢者ケアを貧民救済 事業から分離し, 老年学の研究を進めるべきであ り, 高齢者自身も変化する必要があることが論じ られている. 10 章では, 若い家族は高齢者の施 設入所を望み, 高齢者はその状況を受け入れてい ることが指摘されている。

11 章では, 憲法には個人の自由に関する理念 があるが, 巧妙な方法により高齢者を強制的に施 設入所させる事例が紹介されている.12 章では, 施設の役員や職員の利益に反すると，高齢者への 悪意ある事実が無視される傾向があることが論じ られている.13章では, 入所施設の高齢者は, 職員や役人に対する恐怖心から彼らを批判するこ とができないことが述べられた，14 章では，大 所施設が閉鎖的であることは問題であり, 人間ら しい生活ができるためには, 外部との接触を保障 する必要があることが指摘されている。15 章以 降では, 老人ホームは不要であり, 高齢者が住み 慣れた地域で生活ができるように環境整備が必要 であることなどが記述されている.

本書は, 1950 年前後のスウェーデンの老人 ホームの悲惨な状況を記述しており, 各章は, そ れぞれ興味深い。一般的な質的調査の方法に従っ ているわけではないが，入所施設の悲惨な状況を 改善するために訴え続けてきた知名度と影響力の ある作家によるルポルタージュであり，スウェー デンの当時の入所施設に関心がある学生や研究者 にとっては, 貴重な参考文献である. 